\title{
Beberapa Faktor Risiko Gizi Kurang dan Gizi Buruk pada Balita 12-59 Bulan (Studi Kasus di Kota Pontianak)
}

\author{
Dedi Alamsyah*, Maria Mexitalia**, Ani Margawati**, \\ Suharyo Hadisaputro***, Henry Setyawan**** \\ *Fakultas Ilmu Kesehatan Universitas Muhammadiyah Pontianak, \\ **Fakultas Kedokteran Universitas Diponegoro, ${ }^{* * *}$ Politeknik Kesehatan \\ Semarang, $* * * *$ Fakultas Kesehatan Masyarakat Universitas Diponegoro
}

\begin{abstract}
Background: Moderate and severe malnutrition cases in Pontianak City increases each year although a nutritional improvement program has been held by the Health Department of Pontianak City.

Method: The type of research was observational using the quantitative study design of case control study and the qualitative study through in-depth interview (mixed method). The number of samples was 80 people consisting of 40 people from case and 40 people from control. Assessment of nutritional using anthropometry measurement based on weight for height. Height measurement using microtoise and measure weighting scale.

Results: The multivariate analysis found 2 variables significantly associated with the prevalence of moderate and severe malnutrition in children under five years old aged 12-59 months, i.e.: poor of attitude toward food $(\mathrm{OR}=6.980)$ and poor environmental health $(\mathrm{OR}=$ 5.033). There were 9 variables which were not associated with nutritional status, not given exclusive breastfeeding, energy intake is less, protein intake is less, frequency of Severe Acute Respiratory Infection equal to over three times in the last two months, frequency of diarrhea equal to over three times in the last two months, low monthly family income, number of children more than two, low mother's education, and frequency of watching TV more than two hours a day.

Conclusion: Based on the results above, it can be concluded that the risk factors associated with the prevalence of moderate and severe malnutrition are poor of mother's attitude toward food is poor health and poor environmental.
\end{abstract}

Keywords: RiskFactors; Moderate and Severe Malnutrition; Children; Pontianak

Penulis korespondensi : alamsyahdedi89@yahoo.co.id 


\section{Pendahuluan}

Gizi kurang dan gizi buruk merupakan status kondisi seseorang yang kekurangan nutrisi, atau nutrisinya dibawah rata-rata. Gizi kurang adalah kekurangan bahan-bahan nutrisi seperti protein, karbonhidrat, lemak, dan vitamin yang dibutuhkan oleh tubuh.1 Cara menilai status gizi dapat dilakukan dengan pengukuran antropometrik, klinik, biokimia, dan biofisik. Pengukuran antropometrik dapat dilakukan dengan beberapa macam pengukuran yaitu pengukuran berat badan, tinggi badan, lingkar lengan atas, dan sebagainya.

Dari beberapa pengukuran tersebut, pengukuran Berat Badan (BB) sesuai Tinggi Badan (TB) merupakan salah satu pengukuran antropometik yang baik dengan mengadopsi acuan havard dan WHO-NCHS (World Health Organizatio-National Center For Health Statistics). ${ }^{2}$

Gizi buruk biasanya terjadi pada anak balita dibawah usia 5 tahun. Gizi buruk adalah bentuk terparah dari proses terjadinya kekurangan gizi menahun. ${ }^{2}$ Anak balita usia 12-59 bulan merupakan kelompok umur yang rawan terhadap gangguan kesehatan dan gizi. Pada usia ini kebutuhan mereka meningkat, sedangkan mereka tidak bisa meminta dan mencari makan sendiri dan seringkali pada usia ini tidak lagi diperhatikan dan pengurusannya diserahkan kepada orang lain sehingga risiko gizi buruk akan semakin besar. Anak yang gizi buruk akan mengalami penurunan daya tahan sehingga anak rentan terhadap penyakit infeksi.

Gizi kurang dan gizi buruk secara patofisiologi pada anak balita(12-59 bulan) adalah mengalami kekurangan energi protein, anemia gizi besi, gangguan akibat kekurangan iodium (GAKI) dan kurang vitamin A. Kekurangan sumber dari empat diatas pada anak balita dapat menghambat pertumbuhan, mengurangi daya taha tubuh sehingga rentan terhadap penyakit infeksi, mengakibatkan rendahnya tingkat kecerdasan, penurunan kemampuan fisik, gangguan pertumbuhan jasmani dan mental, stunting, kebutaan serta kematian pada anak balita. $^{4}$

Di Kota Pontianak program perbaikan gizi buruk sudah dilaksanakan, tetapi prevalensi kasus gizi buruk dari tahun 2011, tahun 2012 sampai tahun 2013 mengalami peningkatan. Tahun 2011 sebanyak 41 kasus, tahun 2012 sebanyak 52 kasus dan tahun 2013 sebanyak 53 kasus. ${ }^{5,6,7}$

\section{Metode}

Jenis penelitian ini menggunakan pendekatan observasional dengan menggunakan kajian kuantitatif dan ditunjang dengan pendekatan kualitatif melalui indepth interview. Kajian kuantitatif dengan desain case control study dipilih karena sesuai dengan tujuan penelitian untuk mempelajari berbagai faktor risiko yang berpengaruh terhadap efek dengan cara membandingkan kelompok kasus dengan kelompok kontrol dan dapat digunakan untuk mencari hubungan seberapa jauh faktor risiko yang mempengaruhi efek. ${ }^{8}$

Kelompok kasus adalah ibu yang mempunyai balita gizi kurang $(<-2$ SD) dan gizi buruk $(<-3$ SD) menurut indikator $\mathrm{BB} / \mathrm{TB}$ yang mengalami gejala klinis dan telah di diagnosa oleh dokter, dicatat oleh puskesmas dan dilaporkan ke Dinas Kesehatan Kota Pontianak. Kelompok kontrol adalah ibu yang mempunyai balita 12-59 bulan yang tercatat dengan kriteria gizi baik (-2 SD s/d 2 SD) berdasarkan indikator $\mathrm{BB} / \mathrm{TB}$

Variabel bebas dalam penelitian ini adalah tidak diberikan ASI eksklusif, Asuapan energi dan protein $<80 \% \mathrm{AKG}$, frekuensi ISPA sering ( $\geq 3$ kali dalam 2 bulan), frekuensi diare sering ( $\geq 3$ kali dalam 2 bulan), pendidikan ibu rendah, jumlah anak $>2$, pendapatan keluarga rendah, akses pemanfaatan pelayanan kesehatan jarang, sanitasi lingkungan buruk, Frekuensi menonton TV kurang baik dan Sikap ibu terhadap makanan yang buruk. Pengolah dan analisis data dilakukan dengan menggunakan komputer dengan bantuan program SPSS.

Analisis data dilakukan secara univariat untuk melihat deskripsi variabel penelitian, analisisbivariat dengan menggunakan uji statistik Chi-Square dengan tabel kontingensi $2 \times 2$, dan analisis multivariat dengan menggunakan uji regresi logistik.

\section{Hasil}

Analisis bivariat dimaksudkan untuk mengetahui hubungan antar variabel bebas dengan variabel terikat secara sendirisendiri. Uji statistika yang digunakan yaitu Chi Square digunakan untuk data berskala 
nominal dengan menggunakan Confidence Interval (CI) sebesar 95\% $\quad(\alpha=0,05)$. Uji statistik $\quad C h i \quad S q u a r e$ digunakan untuk menganalisis semua variabel yang diteliti. Pada tabel 1 dibawah ini, diketahui bahwa ada 5 (lima) variabel yang berhubungan dengan kejadian gizi kurang dan gizi buruk pada balita 12-59 bulan yaitu pendidikan ibu rendah $(\mathrm{OR}=7,07$ $\mathrm{P}=0,001)$, jumlah anak $>2$ dalam keluarga $(\mathrm{OR}=2,91 \mathrm{P}=0,040)$, pendapatan $\mathrm{k}$ e $1 \mathrm{u}$ a r g a $\mathrm{r}$ e $\mathrm{nd}$ a h $(\mathrm{O} \mathrm{R}=4,20$ $\mathrm{P}=0,020)$, sanitasi lingkungan buruk $(\mathrm{OR}=4,33 \mathrm{P}=0,004)$ dan sikap ibu terhadap makanan buruk $(\mathrm{OR}=5,76 \mathrm{P}=0,001)$. sedangkan variabel yang tidak berhubungan yaitu tidak diberikan ASI eksklusif, asupan energi kurang dan asupan protein kurang, frekuensi ISPA $\geq 3$ kali dalam dua bulan terakhir, frekuensi diare $\geq 3$ kali dalam dua bulan terakhir, manfaat akses pelayanan kesehatan jarang dan frekuensi menonton televisi $>2$ jam sehari.

\section{Analisa Multivariat}

Hasil analisis multivariat digunakan untuk mengetahui besar pengaruh variabel bebas terhadap variabel terikat, dengan menggunakan uji statistik Logistic Regression yang dalam analisis bivariat mempunyai nilai $p<0,25$. Untuk memperoleh model persamaan yang sesuai dan mendapatkan nilai OR yang telah disesuaikan. Variabel bebas yang mempunyai hubungan $(\mathrm{p}<0,05)$ dari uji bivariat, adalah 1). Pendidikan ibu rendah $(\mathrm{OR}=7,07 \mathrm{P}=0,001) 2)$. jumlah anak $>2$ dalam keluarga $(\mathrm{OR}=2,91 \mathrm{P}=0,040) 3)$. pendapatan keluarga rendah $(\mathrm{OR}=4,20$ $\mathrm{P}=0,020)$ 4). sanitasi lingkungan buruk $(\mathrm{OR}=4,33 \mathrm{P}=0,004$ dan 5). sikap ibu terhadap makanan buruk $(\mathrm{OR}=5,76 \mathrm{P}=0,001)$

Dari hasil perhitungan dan dianalisa dengan menggunakan uji Logistic Regression variabel yang berpengaruh terhadap gizi kurang dan gizi buruk pada anak balita 12-59 bulan dengan batas kemaknaan $\mathrm{p} \leq 0,25$ yaitu sikap ibu terhadap makanan yang buruk $(\mathrm{OR}=6,98 \mathrm{P}=0,002)$ dan sanitasi lingkungan buruk $(\mathrm{OR}=5,03$ $\mathrm{P}=0,012$ ). Untuk memprediksi balita 12-59 bulan yang menderita gizi kurang dan gizi buruk menggunakan rumus persamaan regresi logistik, maka diperoleh nilai:

$$
\begin{aligned}
\mathrm{p} & =\frac{1}{1+\mathrm{e}^{-(2+b 1 \times 1, b 2 \times 2+\ldots . b k \times k)}} \\
& =\frac{1}{1+2,718281^{(-2,820+1,943+1,616)}} \times 100 \% \\
& =0,6767 \times 100 \% \\
& =67,75
\end{aligned}
$$

Probabilitas risiko balita untuk menderita gizi kurang dan gizi buruk tersebut apabila memiliki sikap ibu terhadap makanan yang buruk dan sanitasi lingkungan yang buruk maka akan mengalami gizi kurang dan gizi buruk dengan probabilitas sebesar $67,7 \%$.

Tabel 1. Rangkuman analisa bivariat faktor risiko gizi kurang dan gizi buruk pada balita tahun 2014

\begin{tabular}{clccc}
\hline No. & \multicolumn{1}{c}{ Variabel Penelitian } & $\mathrm{p}$ & $\mathrm{OR}$ & 95\%CI \\
\hline 1. & Pendidikan ibu (rendah) & 0,001 & 7,07 & $2,065-16,079$ \\
2. & Sikap ibu terhadap makanan (buruk) & 0,001 & 5,76 & $2,519-19,850$ \\
3. & Sanitasi lingkungan (buruk) & 0,004 & 4,33 & $1,696-11,069$ \\
4. & Pendapatan keluarga (rendah) & 0,020 & 4,20 & $1,350-13,065$ \\
5. & Jumlah anak (besar) & 0,040 & 2,91 & $1,149-7,393$ \\
6. & Frekuensi ISPA (sering) & 0,479 & 2,18 & $0,504-9,391$ \\
7. & Manfaat akses pelayanan & 0,261 & 1,84 & $0,755-4,493$ \\
& kesehatan (jarang) & & & \\
8. & Asupan protein (-) & 0,567 & 1,65 & $0,525-5,154$ \\
9. & Frekuensi menonton tv (+) & 0,796 & 1,31 & $0,473-3,609$ \\
\hline
\end{tabular}




\begin{tabular}{lllcc}
\hline No. & Variabel Penelitian & $\mathrm{p}$ & $\mathrm{OR}$ & $95 \% \mathrm{CI}$ \\
\hline 11. & Frekuensi diare (sering) & 1,000 & 0,81 & $0,226-2,903$ \\
12. & ASI eksklusif (-) & 0,118 & 0,44 & $0,182-1,087$ \\
\hline
\end{tabular}

Tabel 2. Model akhir analisis regresi logistik faktor risiko gizi kurang dan gizi buruk pada anak balita

\begin{tabular}{crrrcc}
\hline No. & \multicolumn{1}{c}{ Variabel } & Nilai B & Nilai $\mathrm{p}$ & OR & $95 \% \mathrm{CI}$ \\
\hline 1. & Sikap Ibu Terhadap Makanan buruk & 1,943 & 0,002 & 6,98 & $1,998-24,385$ \\
2. & Sanitasi Lingkungan buruk & 1,616 & 0,012 & 5,03 & $1,432-17,683$ \\
\hline
\end{tabular}

\section{Pembahasan}

\section{Faktor risiko yang berpengaruh terhadap kejadian gizi kurang dan gizi buruk.}

\section{Sikap ibu terhadap makanan}

Faktor risiko yang terbukti berpengaruh terhadap kejadian gizi kurang dan gizi buruk adalah sikap ibu terhadap makanan yang buruk dengan OR 6,98, artinya ibu yang mempunyai balita $12-59$ bulan mempunyai risiko menderita gizi kurang dan gizi buruk sebesar 6,98 kali lebih besar bila dibandingkan dengan ibu yang mempunyai balita gizi baik.

Kejadian gizi kurang dan gizi buruk berkaitan dengan sikap ibu terhadap makanan. Sikap terhadap makanan berarti jugaberkaitan dengan kebiasaan makan, kebudayaan masyarakat, kepercayaan dan pemilihan makanan. Budaya adalah daya dari budi yang berupa cipta, karya dan karsa. Budaya berisi norma-norma sosial yakni sendi-sendi masyarakat yang berisi sanksi dan hukuman-hukumannya yang dijatuhkan kepada golongan bilamana yang dianggap baik untuk menjaga kebutuhan dan keselamatan masyarakat itu dilanggar. Norma-norma itu mengenai kebiasaan hidup, adat istiadat, atau tradisi-tradisi hidup yang dipakai secara turun temurun. ${ }^{9}$

Kebiasaan makanan adalah konsumsi pangan (kuantitas dan kualitas), kesukaan makanan tertentu, kepercayaan, pantangan, atau sikap terhadap makanan tertentu. Kebiasaan makan ada yang baik atau dapat menunjang terpenuhinya kecukupan gizi dan ada yang buruk (dapat menghambat terpenuhinya kecukupan gizi), seperti adanya pantangan, atau tabu yang berlawanan dengan konsep-konsep gizi. Masalah yang dapat menyebabkan kekurangan gizi adalah tidak cukup pengetahuan gizi dan kurangnya pengertian tentang kebiasaan makan yang baik. Kebiasaan makan dalam rumah tangga penting untuk diperhatikan, karena kebiasaan makanan mempengaruhi pemilihan dan penggunaan pangan, selanjutnya mempengaruhi tinggi rendahnya mutu makanan rumah tangga. ${ }^{10}$

Persoalan gizi kurang dan gizi buruk pada balita dapat disebabkan sikap atau perilaku ibu yang menjadi faktor dalam pemilihanmakanan yang tidak benar. Pemilahan bahan makanan, tersedianya jumlah makanan yang cukup dan keanekaragaman makanan ini dipengaruhi oleh tingkat pengetahuan ibu tentang makanan dan gizinya. Ketidaktahuan ibu dapat menyebabkan kesalahan pemilihan makanan terutama untuk anak balita, sehingga zat-zat gizi dalam kualitas dan kuantitas tidak cukup untuk memenuhi kebutuhan tubuh. ${ }^{11}$

Hasil penelitian sejalan dengan penelitian sebelumnya, bahwa sikap ibu yang buruk terhadap makanan mempunyai $5 \mathrm{kali}$ lebih besar menderita gizi buruk dibandingkan dengan ibu yang mempunyai sikap terhadap makanan yang baik. ${ }^{12}$

\section{Sanitasi lingkungan}

Sanitasi lingkungan buruk terbukti sebagai faktor risiko kejadian gizi kurang dan gizi buruk pada balita dengan OR 5,03, artinya ibu yang mempunyai balita gizi kurang dan gizi buruk mempunyai risiko 
5,03 kali untuk menderita gizi kurang dan gizi buruk bila dibandingkan dengan ibu yang mempunyai balita gizi baik.Sanitasi lingkungan memiliki peran yang cukup dominan dalam penyedianan lingkungan yang mendukung kesehatan anak dan proses tumbuh kembangnya. Sanitasi lingkungan yang buruk akan menyebabkan anak balita akan lebih muda terserang penyakit infeksi yang akhirnya dapat mempengaruhi status gizi anak.

Sanitasi lingkungan erat kaitannya dengan ketersedian air bersih, ketersedian jamban, jenis lantai rumah, serta kebersihan peralatan makanan, kebersihan rumah, pencahayaan, ventilasi. Makin tersediannya air bersih untuk betuhan sehari-hari, maka makin kecil risiko anak terkena penyakit kurang gizi. ${ }^{13}$

Tingkat sanitasi lingkungan ditentukan oleh berbagai kemungkinan bahwa lingkungan berperan sebagai pembiakan agent hidup, tingkat lingkungan yang tidak sehat bisa diukur dengan penyedian air bersih yang kurang, pembuangan air limbah yang tidak memenuhi persyaratan kesehatan, tidak adanya penyedian dan pemanfaatan tempat pembuangan sampah rumah tangga yang memenuhi persyaratan kesehatan, tidak adanya penyedian sarana pengawasan makanan, serta penyedian sarana perumahan yang tidak memenuhi persyaratan kesehatan. Hal-hal yang menyangkut sanitasi pertama adalah ventilasi.

Perumahan yang penghuninya banyak dan ventilasi yang tidak memenuhi syarat-syarat kesehatan dapat mempermudah dan memungkinkan adanya transisi penyakit dan mempengaruhi kesehatan penghuninya. Kedua adalah pencahayaan, pencahayaan yang cukup untuk penerangan ruangan di dalam rumah merupakan kebutuhan kesehatan manusia. Pencahayaan dapat diperoleh dari pencahayaan dari sinar matahari, pencahayaan dari sinar matahari masuk ke dalam melalui jendela. Celah-celah dan bagian rumah yang terkena sinar matahari hendaknya tidak terhalang oleh benda lain. Ketiga dinding rumah harus bersih, kering dan kuat. Kempat kepadatan penghuni risiko yang ditimbulkan oleh kepadatan penguni rumah terhadap terjadinya penyakit. ${ }^{14}$

Penelitian ini sejalan dengan penelitian yang dilakukan sebelumnya, bahwa penduduk yang tinggal di daerah yang kumuh sangat mendukung terjadinya status gizi balita kurus (gizi kurang) dan sangat kurus (gizi buruk), ${ }^{15}$ serta juga sejalan dengan dengan penelitian sebelumnya bahwa jumlah anggota keluarga, jumlah anak, ekonomi keluarga, BBLR, usia anak, pendidikan ibu, dan sanitasi lingkungan (sumber air minum) adalah penyebab kuat dari kekurangan gizi pada anak. Rumah tangga yang tidak tersedia air bersih memiliki 4 (empat) kali lebih tinggi terhambat pertumbuhannya dibandingkan dengan rumah tangga yang memiliki persedian air bersih. ${ }^{16}$ Namun hasil penelitian iniberbeda dengan penelitian sebelumnya oleh Wahyudi Istiono, dkk di Kabupaten Kulonprogo bahwa tidak ada hubungan yang signifikan antara sanitasi dengan status gizi balita. ${ }^{17}$

\section{Faktor risiko yang tidak berpengaruh terhadap kejadian gizi kurang dan gizi buruk}

\section{ASI eksklusif}

Hasil analisa bivariat menunjukkan bahwa nilai OR : 0,44 (95\% CI 0,182 - 4, 945) $\mathrm{p}=0,180$, artinya tidak ada hubungan antara tidak diberikan ASI eksklusif dengan kejadian gizi kurang dan gizi buruk pada balita. Hasil penelitian ini juga berbeda dengan berbagai penelitian epidemiologis yang menunjukkan bahwa pemberian ASI eksklusif mempunyai keuntungan terhadap kesehatan pada umumnya dan pertumbuhan tinggi badan bayi. ${ }^{18}$

\section{Asupan energi}

Hasil analisa bivariat menunjukkan bahwa nilai OR : $1,18(95 \%$ CI 0,383-3,630) $\mathrm{p}=$ 1,000 , artinya tidak ada hubungan yang bermakna antara asupan energi kurang dengan kejadian gizi kurang dan gizi buruk pada balita. Hasil penelitian ini sejalan dengan penelitian yang lakukan sebelumnya oleh Asrar dan Boediman bahwa tidak ada 
hubungan bermakna antara asupan protein dengan status gizi anak balita menurut indeks $\mathrm{BB} / \mathrm{TB}$ nilai $p$ valuenya sama dengan $0,187 .{ }^{19}$

\section{Asupan protein}

Hasil analisa bivariat menunjukkan bahwa nilai OR : 1,65 (95\% CI 0, 525-5,154) $\mathrm{p}=0,567$, artinya tidak ada hubungan yang bermakna antara asupan protein kurang dengan kejadian gizi kurang dan gizi buruk pada balita. Hasil penelitian ini sejalan dengan penelitian yang lakukan sebelumnya oleh Asrar dan Boediman bahwa tidak ada hubungan bermakna antara asupan protein kurang dengan status gizi anak balita menurut indeks $\mathrm{BB} / \mathrm{TB}$ nilai $p$ valuenya sama dengan $0,187 .{ }^{19}$

\section{Frekuensi ISPA}

Hasil analisa bivariat menunjukkan bahwa nilai OR : 2,18 (95\% CI 0,504-9,391) $\mathrm{p}=0,479$, artinya tidak ada hubungan antara frekuensi ISPA $\geq 3$ kali dalam dua bulan dengan kejadian gizi kurang dan gizi buruk pada balita. Hasil penelitian ini berbeda dengan penelitian di Erbyl bahwa risiko mengalami ISPA sebesar 2 kali lipat lebih tinggi dibandingkan pada kelompok kasus dibandingkan dengan kelompok kontrol. ${ }^{20}$

\section{Frekuensi diare}

Hasil analisa bivariat menunjukan bahwa nilai OR : 0,81 (95\% CI 0,226-2,903) $\mathrm{p}=1,000$, artinya tidak ada hubungan antara frekuensi diare $\geq 3$ kali dalam dua bulan dengan kejadian gizi kurang dan gizi buruk pada balita. Hal ini berbanding lurus dengan frekuensi diare mengingat penyebab kejadian diare antara lain disebabkan oleh karena adanya kontamidasi pada makanan atau peralatan pada saat menyajikan makanan atau kontamidasi akibat tidak mencucui tangan dengan sabun. ${ }^{21}$

\section{Pendapatan keluarga}

Berdasarkan hasil analisa multivariat tentang penghasilan atau pendapatan keluarga perbulan menunjukkan bahwa nilai $\mathrm{p}$ adalah 0,340 dengan OR : 2,16 (95\% CI 0,445-10,489) artinya tidak ada hubungan yang bermakna antara penghasilan rendah atau pendapatan rendah dengan kejadian gizi kurang dan gizi buruk pada balita. Penelitian ini sejalan dengan penelitian sebelumnya oleh Sulistya bahwa pengeluaran atau pendapatan keluarga yang rendah tidak berpengaruh terhadap status gizi anak balita. $^{22}$

\section{Pendidikan ibu}

Berdasarkan hasil analisa multivariat menunjukkan bahwa nilai OR : 2,45 (95\% CI $0,707-8,464) \mathrm{p}=0,158$, artinya tidak ada hubungan yang bermakna antara pendidikan ibu rendah dengan kejadian gizi kurang dan gizi buruk pada balita. Hasil penelitian ini mendukung terhadap hasil penelitian sebelumnya oleh Miller yang menunjukan bahwa tingkat pendidikan ibu yang rendah tidak berpengaruh terhadap kejadian gizi buruk. $^{23}$

\section{Jumlah anak dalam keluarga}

Hasil analisa multivariat menunjukkan bahwa nilai $\mathrm{p}=0,130$ dengan OR : 2,56 (95 \% CI 0,757-8,680), artinya tidak ada hubungan yang bermakna antara jumlah anak $>2$ dalam keluarga dengan kejadian gizi kurang dan gizi buruk pada balita. Hasil penelitian ini tidak sejalan dengan penelitian sebelumnya oleh Kusriadi bahwa besar keluarga sama dengan memiliki tiga orang anak berisiko menderita gizi akut sebesar 1,91 kali. ${ }^{24}$

\section{Akses pemanfaatan yankes}

Berdasarkan hasil analisa bivariat menunjukkan bahwa nilai OR : 1,84 (95\% CI $0,755-4,493) \mathrm{p}=0,261$, artinya tidak ada hubungan yang bermakna antara akses pemanfaatan pelayanan kesehatan jarang dengan kejadian gizi kurang dan gizi buruk pada balita. Hasil penelitian ini sejalan dengan penelitian sebelumnya oleh Kusriadi bahwa pemberian imunisasi pada anak balita, pemantauan pertumbuhan balita, akses dan 
pemanfaatan pelayanan kesehatan tidak ada hubungannya dengan kejadian kekurangan gizi. $^{24}$

\section{Frekuensi menonton televisi (TV)}

Berdasarkan hasil analisa bivariat menunjukkan bahwa nilai OR : 1,31 (95\% CI $0,473-3,609) \mathrm{p}=0,796$, artinya tidak ada hubungan yang bermakna antara frekuensi menonton TV lebih dari dua jam dengan kejadian gizi kurang dan gizi buruk pada balita. Hasil penelitian ini berbeda dengan penelitian sebelumnya oleh Thanna, dkk bahwa anak-anak lebih dari dua tahun tidak boleh menontot sama dengan dua jam televisi perhari. Hal ini dibuktikan dengan meningkat gizi status semakin buruk.25 Hasil penelitian ini sejalan dengan penelitian sebelumnya oleh Azizul Rahman dan Hossain bahwa anak-anak yang ibunya tidak terkena media massa adalah 2,5 kali dan 1,3 kali lebih mungkin anaknya memiliki risiko lebih tinggi menjadi akut kekurangan gizi dari pada anak yang ibunya telah terkena paling sedikit dua media massa. Hal ini dapat disebabkan oleh fakta bahwa sosial dan budaya perempuan maju memiliki paparan media massa dan sehingga mereka dapat mengumpulkan informasi lebih lanjut tentang gizi dan perawatan anak. ${ }^{26}$

\section{Kesimpulan}

Berdasarkan hasil analisis multivariat ditemukan 2 (dua) variabel faktor risiko yang berhubungan secara signifikan dengan kejadian status gizi yaitu sikap ibu terhadap makanan buruk dengan OR 6,98 dan sanitasi lingkungan buruk dengan OR 5,03. Berdasarkan hasi analisis multivariat ditemukan 10 (sepuluh) variabel faktor risiko yang tidak berhubungan dengan kejadian gizi kurang dan gizi buruk yaitu tidak diberikan ASI eksklusif, asupan energi kurang, asupan protein kurang, frekuensi ISPA $\geq 3$ kali dalam dua bulan terakhir, frekuesi diare ISPA $\geq 3$ kali dalam dua bulan terakhir, jumlah anak $>$ 2 , pendidikan ibu rendah, pendapatan keluarga rendah, akses pemanfaatan yankes jarang dan frekuensi menonton tv $>2$ jam sehari.

\section{Ucapan Terimakasih}

Terimakasih kepada pihak Dinas Kesehatan Kota Pontianak yang telah memberi ijin penelitian dan Puskesmas seKota Pontianak beserta petugas gizi puskesmas yang telah memberi data, izin dan memfasilitasi untuk lokasi penelitian. Krisnansari D. 2010. Nutrisi dan Gizi

Daftar Pustaka Buruk. of Health

1. Krisnansari D.2010.Nutrisi dan Gizi Buruk. Mandala of Health:4(1).pp. 60-68.

2. Yetty Nency M, DSA, Muhamad Thohar Arifin,MD.2005.Gizi Buruk, Ancaman Generasi yang Hilang;5 (17).pp.1-4.

3. Arisman M. 2008. Buku Ajar Ilmu Gizi Dalam Daur Kehidupan. Jakar ta: Penerbit Buku Kedokteran EGC.

4. Rahma Faiza S. 2007. Faktor Risiko Kejadian Gizi Buruk pada Balita (12-59 bulan) di Wilayah Kerja Puskesmas Andalas Timur Kota Padang.

5. Sediaoetama AD. 2008. Ilmu Gizi Untuk Mahasiswa dan Profesi Jakarta: Penerbit Dian Rakyat.

6. Dinkes Kota Pontianak. 2013. Profil Dinas Kesehatan Kota Pontianak Tahun 2012.

7. Dinas Kesehatan Kota Pontianak. 2013. Laporan Seksi Gizi Dinas Kesehatan Kota Pontianak Tahun 2013.

8. R. Beaglehole RB, T.Kjellstrom. 1993. Basic Epidemiologi Geneva Switzerland Divisi of Environmental Health. World Health Organization.pp.63.

9. Yudi H. 2007. Hubungan Faktor Sosial dan Budaya dengan Status Gizi Anak Usia 6-24 Bulan di Kecamatan Medan Area Kota Medan. Medan: Universitas Sumatera Utara.

10. Ali Khosman FA, Dadang Sukandar, Hadi Riyadi, Eddy Mudjajanto. 2006. Studi Tentang Pengetahuan Gizi Ibu dan Kebiasaan Makan Pada Rumah Tangga Di Daerah Dataran Tinggi dan Pantai. Gizi dan Pangan.pp.23-28.

11. Julita Nainggolan RZ. 2011. Hubungan antara Pengetahuan dan Sikap Gizi Ibu dengan Status Gizi Balita di Wilayah Kerja Puskesmas Rajabasa Indah Kedokteran.pp.62-72. 
12. Munthofiah S.2008. Hubungan Antara Pengetahuan, Sikap dan Perilaku Ibu de ngan Status Gizi Anak Balita Surakarta:Universitas Sebelas Maret.

13. Soekirman.2000. Ilmu Gizi dan Aplikasinya Untuk Keluarga dan Masyarakat Ilmu Gizi. Jakarta: Dirjen Dikti, DepDiknas.

14. Natalia Puspitawati TS. 2011. Sanitasi Lingkungan yang Tidak Baik Mempengaruhi Status Gizi Pada Balita. Journal Stikes;6(1).pp.78-80.

Hapsari D, Supraptini. 2007. Status Gizi

15. Balita Berdasarkan Kondisi Lingkungan dan Status Ekonomi (Data Riskesdas 2007). Pusat Teknologi Intervensi Kesehatan Masyarakat.pp.103-112.

16. Bomela NJ. 2012. Social, Economic, Health and Environmental Determinants of Child Nutritional Status in Three Central Asia Republics. Public Health Nutrition;12 (10).pp. 1871-1877.

17. Wahyudi Istiono HS, Muhammad Haris, Irnizarifka, Andre Damardana Tahitoe, M. Adrian Hasdianda, Tika Fitria, Riris Sidabutar. 2009. Analisis Faktor-Faktor yang Mempengaruhi Status Gizi Balita Berita Kedokteran Masyarakat; 25(3). pp.150-155.

18. Roesli U. 2008. Mengenal ASI Eksklusif. Edisi ke 3 ed. Jakarta: Trubus Agriwidya.

19. Asrar M,Hadi H, Boediman. 2009. Pola Asuh, Pola Makan, Asupan Zat Gizi Anak Balita Masyarakat Suku Nuaulu di Kecamatan Amahai Kabupaten Maluku Tengah. Gizi Klinik Indonesia; 6(2).pp.84-94.
20. Chalabi DAK. 2013. Cute Respiratoey Infection and Malnutrition Among Children Below 5 Years of Age In Erbil Govermorate, Irak.Eastern Mediteoance Health Journal;19(1).pp.66-72.

21. Hidayat TS Fuad N. 2011. Hubungan Sanitasi Lingkungan, Morbiditas dan Status Gizi Balita Di Indonesia. 34(2).pp.109-133.

22. Sulistya H. 2006. Hubungan Tingkat Asupan Energi dan Protein dengan Kejadian Gizi Kurang Anak Usia 2-5 Tahun. Semarang: Universitas Diponegoro Semarang.

23. Miller JE. 2010. Mothers Education and Childrens Nutritional Status New Evidence From Combodin Asia Development Riview;26(1).pp.134.

24. Kusriadi. 2010. Analisa Faktor Risiko yang Mempengaruhi Kejadian Gizi Kurang pada Balita di Provinsi Nusa Tenggara. Bogor :IPB.

25. Thanna A. Elkholy N, Hassanen and Rasha. 2011. Demographic, SosioEconomic Factors and Physical Activity Affecting The Nutritional Status of Young Children Under Five Years. Journal of America Sciene.

Azizul Rahman SC, D Hossain. 2000. Acute Malnutrition in Bangladesh Children: Levels and Determinants. Rural and Remote Area Health.

26. Azizul Rahman SC, D Hossain. 2000. Acute Malnutrition in Bangladesh Children : Levels and Determinants. Rural and Remote Area Health. 